\title{
ОПЫТ РАЗВИТИЯ РЫНКА ЗЕЛЕНОГО ФИНАНСИРОВАНИЯ В БРАЗИЛИИ
}

\section{EXPERIENCE OF GREEN FINANCE MARKET DEVELOPMENT IN BRAZIL}

\section{S. Panova}

Summary: The analysis of the experience of developing the green finance market in Brazil. Particular attention is paid to the infrastructure of the market for financing environmental projects and the types of green financial instruments that are issued and traded in the Brazilian financial market. It was revealed that with a high correlation between the economic indicators of Brazil and Russia, the market for green financing instruments in Brazil, both in terms of volume and variety of financial instruments, significantly exceeds the Russian one.

Keywords: green financial instruments, market infrastructure for financing environmental projects.

\author{
Панова Светлана Анатольевна \\ д.m.н., профессор, Финансовый университет при \\ Правительстве Российской Федерации \\ SAPanova@fa.ru
}

Аннотация: Проведен анализ опыта развития рынка зеленого финансирования Бразилии. Особое внимание уделено инфраструктуре рынка финансирования экологических проектов и типам зеленых финансовых инструментов, которые эмитированы и обращаются на бразильском финансовом рынке. Выявлено, что при высокой корреляции экономических показателей Бразилии и России, рынок инструментов зеленого финансирования Бразилии и по объему, и по разнообразию финансовых инструментов существенно превосходит российский.

Ключевые слова: зеленые финансовые инструменты, инфраструктура рынка финансирования экологических проектов.

рованных пастбищ, улучшение 5 миллионов гектаров интегрированных систем пахотных земель, животноводства и лесного хозяйства к 2030 году.

Исходя из ее климатических обязательств, потенциал зеленых инвестиций Бразилии в энергетику, транспорт, здания, отходы и промышленную энергоэффективность оценивается в 1,3 трлн. долларов США.

На бразильском финансовом рынке представлены как долговые, так и долевые инструменты финансирования экологических проектов.

Долговые инструменты бразильского финансового рынка включают банковские депозитные сертификаты; корпоративные облигации; сертификаты дебиторской задолженности агробизнеса как долговые ценные бумаги, обеспеченные пулом базовых активов (секьюритизированные облигации); зеленые кредиты, синдицированные кредиты и кредитные линии.

На этом рынке не эмитированы и не обращаются суверенные облигации, хотя следует отметить, что другие страны региона - Аргентина и Чили эмитировали их.

Региональные (субфедеральные) и муниципальные облигации также не эмитированы, но ввиду того, что регионы и муниципалитеты в настоящее время не могут получить стабильный доступ к рынкам капитала. В соответствии с местным законодательством федеральные земли и муниципалитеты могут выпускать только долго- 
вые обязательства с государственной гарантией, которые не были предоставлены из-за финансовых ограничений и ограничений платежеспособности.

Также на финансовом рынке Бразилии не представлены структурированные облигации (в этом регионе эмитированы только Уругваем), проектные облигации, субординированные облигации. В Бразилии еще не было выпущено и облигаций с выплатой вознаграждения за отсутствие воздействия на окружающую среду.

Выпуск зеленых облигаций в Латинской Америке невелик и составляет всего $2 \%$ мирового объема эмиссии зеленых облигаций, но существует значительный потенциал роста этого вида финансовых инструментов во всем регионе [3].

Первые бразильские зеленые облигации были выпущены в июне 2015 года. Сегодня Бразилия является крупнейшим рынком зеленых облигаций в Латинской Америке и Карибском бассейне: на ее долю приходится 5,6 млрд. долларов США, что составляет $41 \%$ от объема выпуска в регионе. На сегодняшний день в обращении находятся 30 выпусков зеленых облигаций 13 эмитентов.

Нефинансовые корпорации являются ведущими эмитентами в Бразилии. На их долю пришлось 84\% из 30 облигаций и 73\% от общей суммы выпущенных облигаций. К другим значимым эмитентам относятся Национальный банк развития (BNDES), Банк Северо-Востока (BNB), Banco da Amazônia SA (BASA), Banco Regional de Desenvolvimento do Extremo Sul (BRDE) и Банк развития Минас-Жерайс (BDMG).

Срок обращения бразильских зеленых облигаций составляет от 5 до 10 лет, особенно для крупных сделок. Около 99\% объема зеленых эмиссий Бразилии и 28 из 30 облигаций попадают в этот диапазон. Только четыре зеленых облигации (две для целлюлозно-бумажной промышленности и две для возобновляемых источников энергии) были выпущены с первоначальным сроком более 20 лет [4].

Что касается долевых финансовых инструментов, то структурированные транши в акции с приоритетным инвестиционным рейтингом, предназначенные для инвесторов, не склонных к риску на финансовом рынке Бразилии не представлены, хотя инфраструктура рынка позволяет осуществить выпуск таких бумаг через дочернюю холдинговую компанию BNDES, которая напрямую инвестирует в компании и фонды посредством владения акциями и покупки облигаций и акций. Подход организации аналогичен государственному инвестиционному фонду, который напрямую капитализирует частные инициативы [5].
В Бразилии существуют фонды прямых инвестиций, которые формируются как «закрытые фонды» и инвестируют в компании, имеющие хороший потенциал роста и оценки. Примерами такого типа фондов в секторе инфраструктуры могут быть InfraBrasil (управляемый ABN AMRO Real) и Logística Brasil (управляемый BRZ Investimentos).

Гибридное финансирование, как правило, от банков развития и международных финансовых организаций, поддерживаемое субординацией траншей в акционерный капитал по-прежнему является инновационным на бразильском рынке капитала и обычно используется только секьюритизационными компаниями и стартапами.

Инфраструктурными институтами финансового рынка Бразилии являются Гарантийный фонд для электроэнергетики (Fundo de Garantia de Energia Elétrica - FGEE), который предоставляет гарантии специализированной компании, созданной для строительства электроэнергетических предприятий, при финансировании, предоставленном федеральным финансовым учреждением и его агентами. Гарантийный фонд инфраструктуры (Fundo Garantidor de Infraestrutura - FGIE) - частный фонд (структурированный ABGF - Guarantee Funds Manager Brazilian Angency), созданный в 2014 году с целью гарантировать, прямо или косвенно, покрытие любых рисков, в том числе неуправляемых, в соответствии с условиями и формами, предусмотренными в его Уставе.

Инструменты и инфраструктура хеджирования риска представлены на рынке Бразилии достаточно широко, существуют Федеральные гарантии, предоставляемые государственным независимым компаниям, таким как государственные агентства развития.

Возможна кредитная гарантия - поручительство берется у секьюритизационной компании. Заемщик должен ежемесячно выплачивать гаранту определенную сумму для обеспечения защиты от убытков в случае невыполнения принципалом обязательств.

Эскроу - счет - счет условного депонирования работает как трехсторонний договор, подписанный двумя сторонами в рамках связанной юридической сделки, и доверительный управляющий (который будет следить за исполнением основного контракта и ему будет поручено хранение активов по гарантии).

Договор залога - в рамках финансирования проекта могут использоваться следующие формы залога: промышленный и коммерческий залог активов; залог дебиторской задолженности; залог договорных позиций и прямых соглашений с контрагентом; залог акций компании специального назначения и узуфрукт на условиях; и 
договор о залоге текущего счета и управлении счетом.

Банковская гарантия - гарантия, предлагаемая финансовыми учреждениями для обеспечения выполнения контрактов с государственным сектором. В этом случае банк выступает поручителем и выдает кредитору гарантийное письмо. Этот инструмент, как правило, предлагает ограниченный источник финансирования и высокие процентные ставки.

Страховой полис, предоставляемый страховыми компаниями, который покрывает риски физического завершения проекта.

Обеспеченные облигации - это бразильская реальная облигация с государственным покрытием, которая может быть выпущена финансовыми организациями, которая поддерживает инвесторов в случае банкротства эмитента.

Инструменты хеджирования валютного риска - форвардный контракт, то есть принятие обязательства по покупке или продаже конкретного актива по валютно- му курсу, ранее согласованному сторонами для защиты экономических агентов от колебаний валютных курсов. Примерами продуктов, доступных в Бразилии, являются: соглашение о форвардной ставке или беспоставочный форвард.

Операции по своповым контрактам характеризуются обменом потоками активов между двумя агентами через промежуточное финансовое учреждение, которым в Бразилии является биржа. Эти операции защищают участников от колебаний цен и устанавливают фиксированную цену для товаров, по которым ведутся переговоры.

Таким образом, рынок финансовой инфраструктуры и финансовых инструментов Бразилии, обеспечивающих финансирование экологических проектов достаточно широк, что позволяет российскому финансовому рынку использовать этот опыт для продвижения аналогичных проектов и реализации целей, определенных Парижским соглашением по климату. Российский рынок зеленых облигаций пока находится в стадии становления [6].

1. Россия как Бразилия. URL: http://www.mirkin.ru/_docs/profil5.pdf

2. Green Infrastructure Investment Opportunities BRAZIL 2019URL: https://www.climatebonds.net/system/tdf/reports/cbi_giio_2019_02c_0.pdf?file=1\&type=no de\&id $=40189 \&$ force $=0$

3. Latin America \& Caribbean Green finance state of the market 2019/URL: https://www.climatebonds.net/files/reports/cbi_lac_sotm_19_web_02.pdf

4. Green bonds global state of the market 2019. URL: https://www.climatebonds.net/resources/reports/green-bonds-global-state-market-2019

5. Blended Finance: fontes mistas de investimento alavancam Programa Vivenda. URL: https://aupa.com.br/programa-vivenda-blended-finance/

6. Рынок «зеленых» облигаций: мировой опыт и перспективы для России; монография/коллектив авторов: под ред. Б.Б. Рубцова. - Москва: КНОРуС.2020. 224 c. 